\title{
Detection of peripheral nerve pathology
}

\section{Comparison of ultrasound and MRI}

Craig M. Zaidman, MD

Michael J. Seelig

Jonathan C. Baker, MD

Susan E. Mackinnon, MD

Alan Pestronk, MD

Correspondence to

Dr. Zaidman:

zaidmanc@neuro.wustl.edu

\section{ABSTRACT}

Objective: To compare accuracy of ultrasound and MRI for detecting focal peripheral nerve pathology, excluding idiopathic carpal or cubital tunnel syndromes.

Methods: We performed a retrospective review of patients referred for neuromuscular ultrasound to identify patients who had ultrasound and MRI of the same limb for suspected brachial plexopathy or mononeuropathies, excluding carpal/cubital tunnel syndromes. Ultrasound and MRI results were compared to diagnoses determined by surgical or, if not performed, clinical/electrodiagnostic evaluation.

Results: We identified 53 patients who had both ultrasound and MRI of whom 46 (87\%) had nerve pathology diagnosed by surgical $(n=39)$ or clinical/electrodiagnostic $(n=14)$ evaluation. Ultrasound detected the diagnosed nerve pathology (true positive) more often than MRI (43/46 vs 31/46, $p<0.001$ ). Nerve pathology was correctly excluded (true negative) with equal frequency by MRI and ultrasound (both 6/7). In 25\% (13/53), ultrasound was accurate (true positive or true negative) when MRI was not. These pathologies were typically $(10 / 13)$ long $(>2 \mathrm{~cm})$ and only occasionally $(2 / 13)$ outside the MRI field of view. MRI missed multifocal pathology identified with ultrasound in 6 of 7 patients, often (5/7) because pathology was outside the MRI field of view.

Conclusions: Imaging frequently detects peripheral nerve pathology and contributes to the differential diagnosis in patients with mononeuropathies and brachial plexopathies. Ultrasound is more sensitive than MRI (93\% vs 67\%), has equivalent specificity (86\%), and better identifies multifocal lesions than MRI. In sonographically accessible regions ultrasound is the preferred initial imaging modality for anatomic evaluation of suspected peripheral nervous system lesions. Neurology ${ }^{\circledR}$ 2013;80:1634-1640

Nerve imaging augments patient management by providing information regarding lesion morphology, anatomic location, relationship of lesions to surrounding soft tissue, and evaluation of areas difficult to evaluate by electrodiagnostic testing. Imaging can also identify peripheral nerve lesions that are not apparent on electrodiagnostic testing. Types of peripheral nerve abnormalities suited to visualization by imaging include changes in nerve caliber, continuity, and echogenicity or magnetic resonance signal characteristics. ${ }^{1-3}$ Imaging can identify peripheral nerve tumors, traumatic neuromas, lacerations, entrapments with nerve damage, inflammation, demyelinating features, and infections. ${ }^{4-15}$ Ultrasound and MRI are the most commonly used methods for visualizing peripheral nerves. Ultrasonography of nerve lesions impacts management beyond the electrodiagnostic findings in as many as $43 \%$ of patients ${ }^{16}$ and, by identifying nerve continuity, can change surgical decisions after traumatic neuropathies. ${ }^{17}$ MRI visualizes nerves, characterizes soft tissue structures when evaluating atypical sites of compression, identifies features of malignancy in peripheral nerve tumors, and provides information on the presence of muscle denervation and atrophy. ${ }^{11,12,18}$ MRI can describe nerve lesions in areas that are difficult to localize using electrodiagnostic studies ${ }^{8,19,20}$ or visualize using ultrasound. Depending on the specific clinical question, MRI or ultrasound can be a peripheral nerve imaging modality of choice. ${ }^{4,6,16,21}$ In this retrospective study of 53 patients with clinical/pathologic diagnoses of 
peripheral nerve lesions other than ulnar or median nerve entrapments, we compared the accuracy of ultrasound and MRI evaluations.

METHODS We retrospectively searched our database of $849 \mathrm{pa}-$ tients referred for neuromuscular ultrasound from June 2007 to October 2011. We excluded patients referred with only idiopathic carpal tunnel syndrome, ulnar neuropathy at the elbow, hereditary neuropathies, acquired inflammatory polyneuropathies, or idiopathic peripheral neuropathies. We reviewed charts of 145 patients evaluated for suspected brachial plexopathy or single or multiple mononeuropathies. Of these, we identified 53 patients who had MRI studies of the same limb and for the same indication as the ultrasound. Diagnosis was based on surgical exploration or histopathology or, if no surgery was performed, the presence or absence of localized nerve pathology was determined by the clinical and electrodiagnostic evaluation (table 1). The sensitivity (test positive/total positive) and specificity (test negative/total negative) of ultrasound and MRI was determined by comparing the reported imaging findings to the diagnostic standard. Imaging studies that were either true-positive or true-negative were termed accurate. Images from inaccurate (false-positive or false-negative) ultrasound and, if available, MRI cases, were reviewed by C.M.Z. (ultrasound) and J.C.B. (MRI). Results of this review are reported but were not utilized to determine sensitivity and specificity because only images of select cases were reviewed. Nerve pathology identified by MRI or ultrasound was typically based on qualitative abnormalities in nerve size, contour, and abnormal signal characteristics.

Multifocal pathology of nerves, defined as more than one discrete abnormality in either the same or multiple nerves in a limb, was identified based on the review of the ultrasound and MRI reports. In these cases, a diagnostic gold standard for each of the multiple lesions identified with ultrasound or MRI was not achievable. We limited sensitivity and specificity analysis of ultrasound and MRI to a single lesion in each patient, identified by surgical exploration. We also report the ultrasound and MRI findings of cases with multifocal pathology and inferred the pathologic cause for each lesion from the histopathologic findings from another lesion in the same patient or the clinical, electrodiagnostic, and radiographic findings.

All ultrasound examinations were performed by C.M.Z. using Philips HD11xe or iU22 ultrasound systems with a linear L12-5 or L17-5 transducer. MRI, performed at multiple imaging centers, included multiplanar and multisequence protocols

\begin{tabular}{|c|c|c|c|c|}
\hline \multirow{2}{*}{$\begin{array}{l}\text { Table } 1 \\
\text { Patient no. }\end{array}$} & \multicolumn{4}{|c|}{ Subjects with diagnosis determined by clinical or electrodiagnostic findings } \\
\hline & Clinical findings & Electrodiagnostic findings & MRI & Ultrasound \\
\hline 16 & $\begin{array}{l}\text { Unilateral hand weakness and } \\
\text { remote history of trauma }\end{array}$ & $\begin{array}{l}\text { Brachial plexopathy affecting } \\
\text { medial cord or lower trunk }\end{array}$ & $\begin{array}{l}\text { False-negative: normal brachial } \\
\text { plexus }\end{array}$ & $\begin{array}{l}\text { True-positive: enlargement of lower } \\
\text { trunk }\end{array}$ \\
\hline 17 & $\begin{array}{l}\text { Foot drop after knee replacement } \\
\text { surgery }\end{array}$ & Sciatic neuropathy & False-negative: normal sciatic nerve & $\begin{array}{l}\text { False-negative: normal peroneal, } \\
\text { tibial, and poorly visualized sciatic } \\
\text { nerve }\end{array}$ \\
\hline 21 & $\begin{array}{l}\text { Bilateral foot drop, right worse than } \\
\text { left }\end{array}$ & $\begin{array}{l}\text { Asymmetric axonal peripheral } \\
\text { neuropathy, right worse than left }\end{array}$ & $\begin{array}{l}\text { True-negative: no nerve } \\
\text { abnormalities; muscle denervation } \\
\text { suggestive of peripheral neuropathy }\end{array}$ & $\begin{array}{l}\text { True-negative: no focal nerve } \\
\text { abnormalities; slightly reduced } \\
\text { nerve size in right compared to left } \\
\text { leg possibly from axon loss }\end{array}$ \\
\hline 23 & $\begin{array}{l}\text { Acute foot drop and pain after } \\
\text { trauma while running }\end{array}$ & Peroneal neuropathy & $\begin{array}{l}\text { True-positive: intramuscular } \\
\text { hematoma at fibular neck }\end{array}$ & $\begin{array}{l}\text { True-positive: intramuscular } \\
\text { hematoma abutting peroneal nerve } \\
\text { at fibular neck }\end{array}$ \\
\hline 25 & Leg pain and weakness & Sciatic neuropathy & $\begin{array}{l}\text { True-positive: enlarged, enhancing } \\
\text { proximal sciatic nerve }\end{array}$ & $\begin{array}{l}\text { True-positive: enlarged and } \\
\text { hyperechoic proximal sciatic nerve }\end{array}$ \\
\hline 28 & Idiopathic unilateral foot drop & Peroneal neuropathy & $\begin{array}{l}\text { True-positive: enlargement, edema, } \\
\text { and enhancement in peroneal nerve } \\
\text { at fibular neck }\end{array}$ & $\begin{array}{l}\text { True-positive: hypoechoic signal and } \\
\text { mild enlargement in peroneal nerve } \\
\text { at fibular neck }\end{array}$ \\
\hline 29 & $\begin{array}{l}\text { Neurofibromatosis Type } 1 \text {, } \\
\text { prior resections of intraneural } \\
\text { neurofibromas, complains of axillary } \\
\text { mass that when palpated causes } \\
\text { dysesthesia in the hand }\end{array}$ & Not performed & $\begin{array}{l}\text { False-negative: normal nerves in the } \\
\text { axilla }\end{array}$ & $\begin{array}{l}\text { True-positive: mass in median nerve } \\
\text { in axilla }\end{array}$ \\
\hline 36 & Calf weakness & Partial tibial neuropathy & $\begin{array}{l}\text { False-negative: normal tibial and } \\
\text { sciatic nerve }\end{array}$ & $\begin{array}{l}\text { True-positive: enlarged tibial nerve } \\
\text { and tibial portion of sciatic nerve }\end{array}$ \\
\hline 38 & $\begin{array}{l}\text { Idiopathic unilateral foot drop and } \\
\text { leg weakness }\end{array}$ & Lumbosacral plexopathy & $\begin{array}{l}\text { False-negative: normal plexus and } \\
\text { sciatic nerve }\end{array}$ & $\begin{array}{l}\text { True-positive: enlarged, hypoechoic } \\
\text { proximal sciatic nerve (gluteal level) }\end{array}$ \\
\hline 42 & $\begin{array}{l}\text { Progressive hand numbness in digits } \\
1-3\end{array}$ & Proximal median neuropathy & $\begin{array}{l}\text { False-negative: normal median } \\
\text { nerve }\end{array}$ & $\begin{array}{l}\text { True-positive: enlargement of } \\
\text { proximal median nerve }\end{array}$ \\
\hline 47 & $\begin{array}{l}\text { Rheumatoid arthritis and } \\
\text { enlargement of distal volar forearm, } \\
\text { normal strength and sensation }\end{array}$ & Not performed & True-negative: flexor tenosynovitis & True-negative: flexor tenosynovitis \\
\hline 51 & $\begin{array}{l}\text { NF1 and progressive unilateral hand } \\
\text { weakness and numbness }\end{array}$ & Cervical radiculopathy & $\begin{array}{l}\text { True-positive: cervical radiculopathy } \\
\text { with nerve root enlargement }\end{array}$ & $\begin{array}{l}\text { True-positive: cervical nerve root } \\
\text { enlargement and multifocal nerve } \\
\text { enlargements in median and ulnar } \\
\text { nerve }\end{array}$ \\
\hline 52 & $\begin{array}{l}\text { Wrist drop and hand numbness after } \\
\text { gunshot wound }\end{array}$ & Radial neuropathy & $\begin{array}{l}\text { False-negative: no nerve } \\
\text { abnormalities }\end{array}$ & $\begin{array}{l}\text { True-positive: enlargement of radial } \\
\text { and median nerves at site of } \\
\text { penetrating trauma }\end{array}$ \\
\hline 53 & Hand numbness & $\begin{array}{l}\text { Cervical radiculopathy of nerve root } \\
5 \text { or } 6\end{array}$ & $\begin{array}{l}\text { False-negative: normal cervical } \\
\text { roots and plexus }\end{array}$ & $\begin{array}{l}\text { True-positive: focal enlargement of } \\
\text { C5 root suggestive of peripheral } \\
\text { nerve tumor }\end{array}$ \\
\hline
\end{tabular}


and most $(\mathrm{n}=36)$ included IV contrast. All clinical, surgical, electrodiagnostic, or pathologic evaluations were performed at Washington University in St. Louis. Examiners were not blinded to the clinical findings or results of other diagnostic tests. Neither images nor the reports from the first performed imaging study (MRI or ultrasound) were reviewed prior to acquiring/interpreting the second imaging study (ultrasound or MRI). Tumor size was determined by the largest linear (width, height, or length) measurement from the ultrasound or MRI. For identifying the location of pathology, the popliteal fossa was included with the leg rather than the thigh, and the antecubital fossa was included with the forearm.

The study was approved by the Washington University Institutional Review Board. All results are mean (SD) unless otherwise specified. Normal distributions were assessed using the KolmogorovSmirnov test. Continuous variables were compared with a 2-tailed paired $t$ test for parametric or a related sample Wilcoxon signed rank test for nonparametric data and proportions were compared with McNemar test ${ }^{22}$ using VassarStats.net and PASW statistics version 18.

RESULTS The 53 patients ranged in age from 1 to 78 years. A total of 25 were male. Diagnosis was determined by surgical evaluation in $39(74 \%)$, by clinical and electrodiagnostic examination in $12(23 \%)$, and by clinical examination only in 2 (4\%) (table 1$)$. In patients who underwent surgery, the time interval between imaging and surgery was less for ultrasound than MRI (50 vs 125 days, $p<0.001$ ). In patients who did not undergo surgery, the time interval between imaging and the clinical/electrodiagnostic evaluation was similar between ultrasound and MRI (11 vs 29 days, $p=0.05$ ). The MRI examination preceded the ultrasound in 30/53 (57\%) subjects.

Pathology involving the nerve was diagnosed in 46 patients $(87 \%)$ and excluded in 7 (13\%, figure 1). Diagnoses included peripheral nerve sheath tumors $(\mathrm{n}=18)$, traumatic $(n=10)$ or idiopathic $(n=8)$ mononeuropathy/plexopathy, fibrosis $(n=4)$, compression by ganglion/synovial cysts $(n=4)$ or other soft-tissue structures $(\mathrm{n}=3)$, non-nerve soft tissue tumor $(\mathrm{n}=3)$, intraneural granuloma $(n=1)$, vasculitis $(n=1)$, and foot drop due to asymmetric peripheral neuropathy $(\mathrm{n}=1)$. Nerve pathology $(\mathrm{n}=46)$ was large $(>2 \mathrm{~cm})$ in $34(74 \%)$, small $(<1 \mathrm{~cm})$ in $3(7 \%)$, between 1 and $2 \mathrm{~cm}$ in 7 $(15 \%)$, and not measured in $2(4 \%)$. Pathologies (single and multiple) were detected in the brachial plexus/axilla $(\mathrm{n}=7)$, arm $(\mathrm{n}=9)$ and forearm $(\mathrm{n}=10)$, thigh $(\mathrm{n}=9)$, and leg $(\mathrm{n}=13)$.

\section{Figure 1 Flow diagram of study design and results}

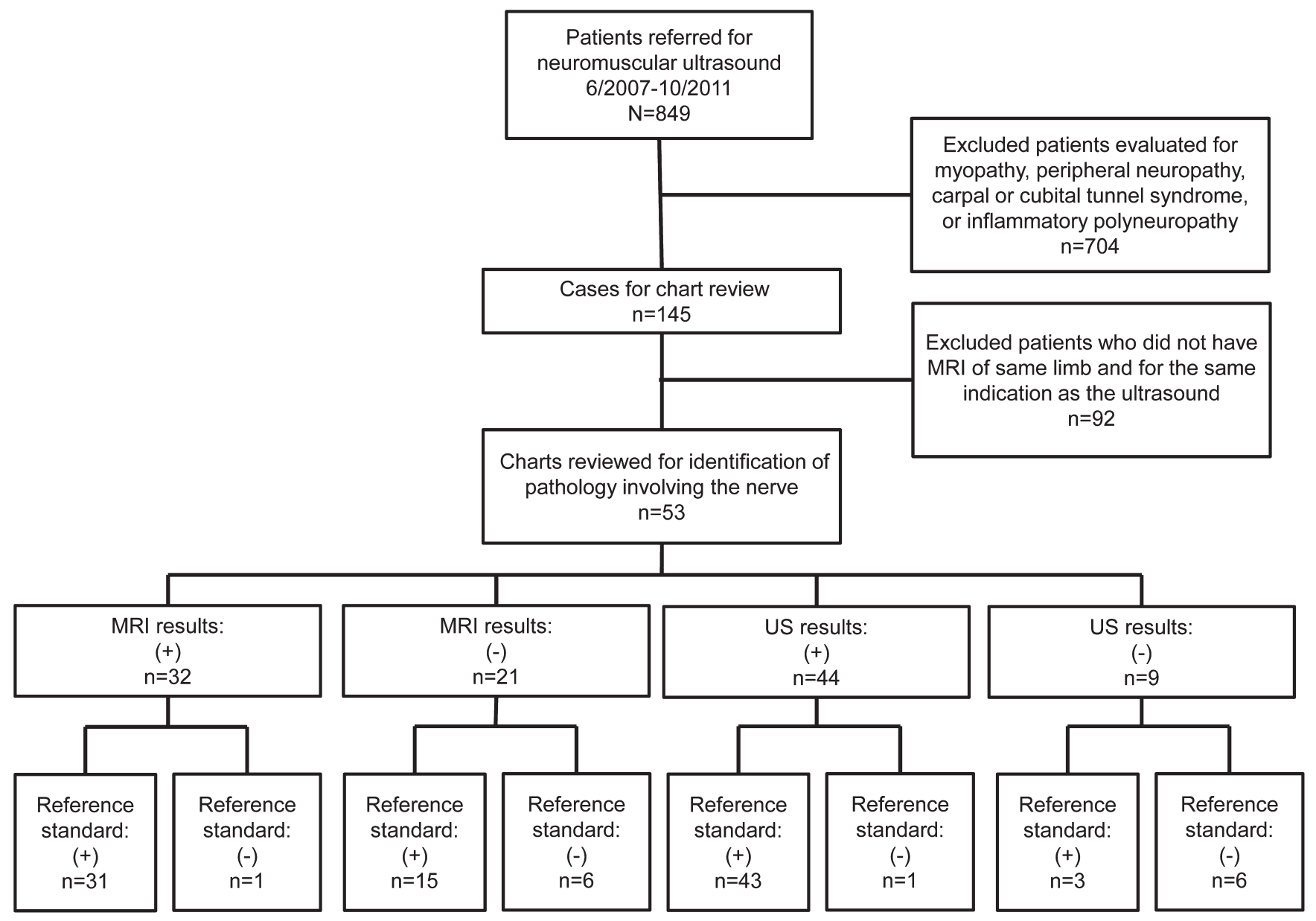

US $=$ ultrasound 
Ultrasound detected lesions more frequently than MRI ( $43 / 46$ vs $31 / 46$; sensitivity $93 \%$ vs $67 \%$; $p<$ 0.001, 2-tailed McNemar) and excluded nerve pathology equally to MRI (6/7; specificity both $86 \%)$. Ultrasound was accurate in more cases (49/53 [93\%]) than MRI (37/53 [70\%], $p=0.002$, 2-tailed McNemar) (table 2). In 13 (25\%) cases, ultrasound accurately identified pathology that was either not seen, or incorrectly identified, on MRI. Pathology accurately identified on ultrasound but not MRI included enlarged nerves $(\mathrm{n}=8)$, peripheral nerve sheath tumor $(\mathrm{n}=3)$, compression by anomalous muscle $(\mathrm{n}=1)$, and a hemangioma $(n=1)$. The hemangioma was incorrectly identified as being likely intraneural pathology (peripheral nerve sheath tumor) on MRI but was correctly identified as an extraneural soft tissue mass on ultrasound. Pathology accurately identified on ultrasound but not MRI was often (10/13 [77\%]) larger than 2 centimeters and in each of these, the long axis (in plane with the long axis of the nerve) was the largest linear dimension. Pathology missed on MRI but not ultrasound was only occasionally $(2 / 13 ; 15 \%)$ outside the field of view of the MRI study. In the 13 cases with accurate ultrasound but not MRI, there was no difference in the interval from the time of diagnosis to the ultrasound or MRI $(p=0.08)$.

In 11 patients with inaccurate MRI (of 16 total), all false-negative, imaging using a $1.5 \mathrm{~T}$ magnet was performed and interpreted at Washington University Medical Center and was available for review. Review resulted in accurately identified nerve pathology in 6 (54\%), each of which had an accurate ultrasound. Review of all 4 inaccurate ultrasound images did not result in any revisions.

Multifocal pathology was identified only by ultrasound in 6 cases and by both MRI and ultrasound in one case (table 3). Multifocal pathology identified on ultrasound was outside the field of view of the MRI in most $(5 / 7 ; 71 \%)$ cases.

\begin{tabular}{|c|c|c|c|c|c|c|c|}
\hline Table 2 & Seventeen patients with in & naccurate MR & or ultrasound findings & & & & \\
\hline \multirow[b]{2}{*}{ Patient no. } & \multicolumn{2}{|c|}{ Neuroimaging findings of peripheral nerve } & \multirow[b]{2}{*}{ Diagnosis } & \multirow[b]{2}{*}{$\begin{array}{l}\text { Surgical } \\
\text { evaluation }\end{array}$} & \multirow[b]{2}{*}{$\begin{array}{l}\text { Lesion } \\
\text { size, } \mathrm{cm}\end{array}$} & \multirow[b]{2}{*}{ Location } & \multirow[b]{2}{*}{ Nerve } \\
\hline & Ultrasound & MRI & & & & & \\
\hline 3 & Normal $^{a}$ & Normal $^{a}$ & Neuroma & Yes & $<1$ & Distal arm & $\begin{array}{l}\text { Medial antebrachial } \\
\text { cutaneous }\end{array}$ \\
\hline 6 & Normal $^{a}$ & Normal $^{a}$ & Postradiation fibrosis & Yes & $\begin{array}{l}\text { Not } \\
\text { measured }\end{array}$ & Neck & Brachial plexus \\
\hline 10 & $\begin{array}{l}\text { Compression by anomalous } \\
\text { abductor digit minimi }\end{array}$ & $\begin{array}{l}\text { No mass } \\
\text { identified }{ }^{a, b}\end{array}$ & Anomalous muscle & Yes & $>2$ & Wrist & Ulnar \\
\hline 16 & Enlarged, hypoechoic & Normal $^{a}$ & Traumatic neuroma & No & $>2$ & Neck & $\begin{array}{l}\text { Lower trunk, brachial } \\
\text { plexus }\end{array}$ \\
\hline 17 & Normal $^{a}$ & Normal $^{a}$ & Traumatic neuropathy & No & $\begin{array}{l}\text { Not } \\
\text { measured }\end{array}$ & Proximal leg & Sciatic \\
\hline 24 & Disrupted fascicles ${ }^{a}$ & Normal & $\begin{array}{l}\text { Traumatic plexopathy, no gross } \\
\text { abnormality in nerve identified }\end{array}$ & Yes & $\begin{array}{l}\text { Not } \\
\text { measured }\end{array}$ & Proximal arm & Ulnar \\
\hline 29 & $\begin{array}{l}\text { Defined, focal enlargement } \\
\text { consistent with tumor }\end{array}$ & Normal $^{a}$ & $\begin{array}{l}\text { Neurofibroma (patient has } \\
\text { neurofibromatosis and prior } \\
\text { resections of neurofibromas) }\end{array}$ & No & $1-2$ & Axilla & Median \\
\hline 32 & $\begin{array}{l}\text { Defined, focal enlargement } \\
\text { consistent with tumor }\end{array}$ & Normal $^{a}$ & Neurofibroma & Yes & $>2$ & Axilla & Ulnar/medial cord \\
\hline 36 & Enlarged, hypoechoic & Normala ${ }^{a, c}$ & Idiopathic neuropathy & No & $<1$ & Proximal leg & Tibial \\
\hline 38 & Enlarged proximal sciatic nerve & Normal $^{a}$ & $\begin{array}{l}\text { Idiopathic sciatic/lumbosacral } \\
\text { plexopathy }\end{array}$ & No & $>2$ & Proximal leg & Sciatic \\
\hline 40 & $\begin{array}{l}\text { Defined area of intraneural } \\
\text { fascicular enlargement, tumor }\end{array}$ & $\begin{array}{l}\text { No mass } \\
\text { identified } a, b\end{array}$ & Intraneural caseating granuloma & Yes & $<1$ & Distal arm & Median \\
\hline 42 & Enlarged & Normal $^{a}$ & Idiopathic neuropathy & No & $>2$ & Proximal arm & Median \\
\hline 45 & Enlarged throughout arm & $\begin{array}{l}\text { Entrapment, } \\
\text { elbow }^{\mathrm{a}}\end{array}$ & Vasculitis & Yes & $>2$ & $\begin{array}{l}\text { Proximal and } \\
\text { distal arm }\end{array}$ & Ulnar \\
\hline 48 & Enlarged & Normal $^{a}$ & Traumatic neuropathy & Yes & $>2$ & Proximal leg & Tibial \\
\hline 49 & $\begin{array}{l}\text { Soft-tissue mass abutting but } \\
\text { not arising from nerves }\end{array}$ & $\begin{array}{l}\text { Nerve sheath } \\
\text { tumor }^{\mathrm{a}}\end{array}$ & Hemangioma & Yes & $>2$ & Proximal arm & $\begin{array}{l}\text { Near ulnar/medial } \\
\text { antebrachial cutaneous }\end{array}$ \\
\hline 52 & Enlarged, hypoechoic & Normal $^{a}$ & Traumatic neuropathy & No & $>2$ & Proximal arm & Radial \\
\hline 53 & $\begin{array}{l}\text { Defined, focal enlargement } \\
\text { consistent with tumor }\end{array}$ & Normal $^{a}$ & Idiopathic neuropathy & No & $>2$ & Neck & C5 root, upper trunk \\
\hline
\end{tabular}


Table 3 Multifocal nerve pathology: Ultrasound and MRI

\begin{tabular}{|c|c|c|c|c|c|}
\hline Patient no. & Lesion location & Nerve & $\begin{array}{l}\text { Detected by } \\
\text { ultrasound }\end{array}$ & $\begin{array}{l}\text { Detected by } \\
\text { MRI }\end{array}$ & Pathology \\
\hline \multirow[t]{2}{*}{12} & Distal forearm & Median & Yes & Yes & Schwannoma \\
\hline & Proximal arm & Ulnar & Yes & $\mathrm{No}^{\mathrm{a}}$ & Schwannoma \\
\hline \multirow[t]{3}{*}{15} & Proximal arm & Median & Yes & Yes & Schwannoma \\
\hline & Elbow & Ulnar & Yes & $\mathrm{No}^{\mathrm{a}}$ & Entrapment \\
\hline & Wrist & Median & Yes & $\mathrm{No}^{\mathrm{a}}$ & Entrapment \\
\hline \multirow[t]{4}{*}{37} & Proximal arm (right) & Ulnar & Yes & Yes & Fibrotic thickening \\
\hline & Distal arm (right) & Ulnar & Yes & $\mathrm{No}^{\mathrm{a}}$ & Fibrotic thickening \\
\hline & Proximal arm (left) & Ulnar & Yes & Yes & Fibrotic thickening \\
\hline & Distal arm (left) & Median & Yes & $\mathrm{No}^{\mathrm{a}}$ & Fibrotic thickening \\
\hline 41 & Proximal/distal arm & Multiple & Yes & Yes & Schwannomatosis \\
\hline \multirow[t]{2}{*}{44} & Proximal arm & Radial & Yes & Yes & Traumatic neuroma \\
\hline & Wrist & Median & Yes & $\mathrm{No}^{\mathrm{a}}$ & Entrapment \\
\hline \multirow[t]{7}{*}{51} & Distal arm & Median & Yes & $\mathrm{No}^{\mathrm{a}}$ & Neurofibroma \\
\hline & Distal arm & Ulnar & Yes & $\mathrm{No}^{\mathrm{a}}$ & Neurofibroma \\
\hline & Wrist & Median & Yes & $\mathrm{No}^{\mathrm{a}}$ & Entrapment \\
\hline & Proximal arm & Ulnar & Yes & No & Neurofibroma \\
\hline & Axilla & Median & Yes & No & Neurofibroma \\
\hline & Axilla & Ulnar & Yes & No & Neurofibroma \\
\hline & Neck & Plexus & Yes & Yes & Neurofibroma \\
\hline \multirow[t]{2}{*}{52} & Proximal arm/axilla & Radial & Yes & No & Traumatic neuroma \\
\hline & Proximal arm/axilla & Median & Yes & No & Traumatic neuroma \\
\hline
\end{tabular}

a Outside the field of view of the MRI.

DISCUSSION In this retrospective study of patients with mononeuropathies or brachial plexopathies, ultrasound of accessible regions detected neuropathology more frequently $(p<0.001)$ than MRI. Ultrasound was more sensitive ( $93 \%$ vs $67 \%$ ), similarly specific $(86 \%)$, and identified more multifocal nerve pathologies than MRI. The greater sensitivity of ultrasound than MRI is not likely due to differences in the timing of the 2 studies. We found no difference in the time intervals between imaging and diagnosis in patients with inaccurate MRI but not ultrasound. A superior or additive sensitivity of ultrasound to MRI is supported by previous reports of positive sonographic imaging identifying peripheral nerve lesions not detected by MRI or electrodiagnostic testing. ${ }^{7}$ The sensitivity of MRI for detection of peripheral nerve tumors in our study $(67 \%)$ is similar to a prior study $(75 \%) .{ }^{23}$ Based on these findings, we recommend ultrasound as opposed to conventional MRI as the preferred initial imaging modality for radiologic evaluation of suspected peripheral nervous system lesions (figure 2).

Nerve pathology can be difficult to read on MRI even at a tertiary care center with experienced examiners. Eleven of the inaccurate MRI studies were performed at our tertiary care center and read by radiologists with expertise in MRI of the nervous/musculoskeletal system. The nerve pathology found on ultrasound was ultimately identified in over half (54\%) of the "false-negative" MRI after re-review with our musculoskeletal radiologist.

Prospective, blinded studies will determine the comparative accuracy, sensitivity, and specificity of ultrasound and MRI in detecting different types of peripheral nerve lesions. Our retrospective study included a high proportion of patients with nerve lesions $(87 \%)$. This frequency could be due to ascertainment bias and likely does not represent all patients with suspected mononeuropathies/brachial plexopathies. Diagnosis in this study was determined by either surgical confirmation or clinical/electrodiagnostic findings, which may not detect all pathologies. However, the high proportion of patients in this study with nerve lesions and low number of falsepositive results from imaging argues against a high rate of unidentified pathology. Although the images and reports of the MRI studies were not reviewed prior to performing or interpreting the ultrasound study, examiners were not blinded to the results of other diagnostic tests. This could have affected the imaging results. Our 
of ultrasound over MRI for detecting peripheral nerve pathology include lower cost, rapidity of examination, higher spatial resolution, imaging of the nerve in continuity (without slicing), and ease of side-to-side comparisons. Ultrasound may better detect subtle changes in nerve caliber. This is important because peripheral nerve pathology is often fusiform in shape and can extend along the length of the nerve without greatly altering its cross-section area. In our study, all pathologies greater than 2 centimeters that were missed with MRI but not ultrasound were largest along the length (long axis) of the nerve. Advantages of MRI over ultrasound include superior contrast between tissues, imaging of structures that are deep or surrounded by bone, and tissue characterization using multisequence analysis and IV contrast. The superior tissue characterization with MRI may affect differential diagnosis. For instance, a prior study of lepromatous neuropathy found that although MRI and ultrasound were equivalent for detecting lesions, MRI was superior in determining which were active. ${ }^{27}$ Finally, neither ultrasound nor MRI can detect pathology that is outside the field of view. We found that MRI frequently missed multifocal (71\%) and occasionally single pathologies identified with ultrasound because lesions fell outside the area visualized by the MRI study. To maximize the advantages and minimize the limitations of each imaging modality, we generally recommend a stepwise approach of ultrasound followed by MRI for evaluating peripheral nerves (figure 2). Exceptions to this rule include evaluation of suspected lesions in areas that are poorly visualized by ultrasound, including nerves that lie very deep or beneath bone (i.e., radiculopathy/root avulsion, subclavicular brachial plexus, proximal sciatic nerve, lumbosacral plexus).

In conclusion, imaging with MRI or ultrasound frequently detects pathology in and informs the differential diagnosis of suspected mononeuropathies and plexopathies. Ultrasound is more accurate than conventional MRI for evaluating suspected peripheral nervous system lesions and identifying multifocal pathology. As ultrasound is less expensive than MRI and can be performed at the bedside, we recommend it for the initial radiographic evaluation of nerves as a routine adjunct to the clinical and electrodiagnostic evaluation. In certain instances, MRI may confer additional diagnostic advantages to ultrasound such as improved tissue characterization and imaging of deep or bone-encased structures. Interpretation of both MRI and ultrasound of peripheral nerves requires availability of clinical differential diagnoses (possible lesion location) and experience in performing studies.

\section{AUTHOR CONTRIBUTIONS}

Dr. Zaidman: study concept and design, acquisition of data, interpretation, and critical revision of manuscript. Michael Seelig: acquisition of data, interpretation, and critical revision of manuscript. Dr. Baker: acquisition of data,
MRI and ultrasound each have unique advantages and limitations for imaging nerve pathology. Advantages 
interpretation, and critical revision of manuscript. Dr. Mackinnon and Dr. Pestronk: data interpretation and critical revision of manuscript.

\section{STUDY FUNDING}

Supported by the Washington University Neuromuscular Research Fund, The Barnes-Jewish Foundation/Institute for Clinical and Translation Science, and the ASPIRE program.

\section{DISCLOSURE}

C. Zaidman received salary support (5\%) from NIH R01AR060850-01A, provided expert witness testimony, and performs clinical imaging as part of his practice. M. Seelig reports no disclosures relevant to the manuscript. J. Baker is a research consultant for Biomedical Systems, provided expert witness testimony, and performs clinical imaging as part of his practice. S. Mackinnon reports no disclosures relevant to the manuscript. A. Pestronk receives revenue related to antibody patent licenses from Athena; owns stock in Johnson \& Johnson; directs the Washington University Neuromuscular Clinical Laboratory, which performs antibody testing; and receives research support from the NIH, Muscular Dystrophy Association, Neuromuscular Research Fund, Insmed, Knopp, Cytokinetics, Biogen Idec, ISIS, Genzyme, GSK, Ultragenyx, and Sanofi. Go to Neurology.org for full disclosures.

Received September 12, 2012. Accepted in final form December 14, 2012.

\section{REFERENCES}

1. Kermarrec E, Demondion X, Khalil C, Le Thuc V, Boutry N, Cotten A. Ultrasound and magnetic resonance imaging of the peripheral nerves: current techniques, promising directions, and open issues. Semin Musculoskelet Radiol 2010;14:463-472.

2. Lin DC, Nazarian LN, O'Kane PL, McShane JM, Parker L, Merritt CR. Advantages of real-time spatial compound sonography of the musculoskeletal system versus conventional sonography. AJR Am J Roentgenol 2002;179:1629-1631.

3. Klauser AS, Peetrons P. Developments in musculoskeletal ultrasound and clinical applications. Skeletal Radiol 2010; 39:1061-1071.

4. Chiou HJ, Chou YH, Chiou SY, Liu JB, Chang CY. Peripheral nerve lesions: role of high-resolution US. Radiographics 2003;23:e15.

5. Fornage BD. Peripheral nerves of the extremities: imaging with US. Radiology 1988;167:179-182.

6. Grant GA, Britz GW, Goodkin R, Jarvik JG, Maravilla K, Kliot M. The utility of magnetic resonance imaging in evaluating peripheral nerve disorders. Muscle Nerve 2002;25: 314-331.

7. Lee FC, Singh H, Nazarian LN, Ratliff JK. High-resolution ultrasonography in the diagnosis and intraoperative management of peripheral nerve lesions. J Neurosurg 2011;114: 206-211.

8. Ochi M, Ikuta Y, Watanabe M, Kimori K, Itoh K. The diagnostic value of MRI in traumatic brachial plexus injury. J Hand Surg Br 1994;19:55-59.

9. Saifuddin A. Imaging tumours of the brachial plexus. Skeletal Radiol 2003;32:375-387.

10. Stull MA, Moser RP Jr, Kransdorf MJ, Bogumill GP, Nelson MC. Magnetic resonance appearance of peripheral nerve sheath tumors. Skeletal Radiol 1991;20:9-14.

11. Van Herendael BH, Heyman SR, Vanhoenacker FM, et al. The value of magnetic resonance imaging in the differentiation between malignant peripheral nerve-sheath tumors and non-neurogenic malignant soft-tissue tumors. Skeletal Radiol 2006;35:745-753

12. Wasa J, Nishida Y, Tsukushi S, et al. MRI features in the differentiation of malignant peripheral nerve sheath tumors and neurofibromas. AJR Am J Roentgenol 2010; 194:1568-1574.

13. Murphey MD, Smith WS, Smith SE, Kransdorf MJ, Temple HT. From the archives of the AFIP. Imaging of musculoskeletal neurogenic tumors: radiologic-pathologic correlation. Radiographics 1999;19:1253-1280.

14. Zaidman CM, Al-Lozi M, Pestronk A. Peripheral nerve size in normals and patients with polyneuropathy: an ultrasound study. Muscle Nerve 2009;40:960-966.

15. Cartwright MS, Chloros GD, Walker FO, Wiesler ER, Campbell WW. Diagnostic ultrasound for nerve transection. Muscle Nerve 2007;35:796-799.

16. Padua L, Liotta G, Di Pasquale A, et al. Contribution of ultrasound in the assessment of nerve diseases. Eur J Neurol 2012;19:47-54.

17. Hollister AM, Simoncini A, Sciuk A, Jordan J. High frequency ultrasound evaluation of traumatic peripheral nerve injuries. Neurol Res 2012;34:98-103.

18. Li CS, Huang GS, Wu HD, et al. Differentiation of soft tissue benign and malignant peripheral nerve sheath tumors with magnetic resonance imaging. Clin Imaging 2008;32: 121-127.

19. Medina LS, Yaylali I, Zurakowski D, Ruiz J, Altman NR, Grossman JA. Diagnostic performance of MRI and MR myelography in infants with a brachial plexus birth injury. Pediatr Radiol 2006;36:1295-1299.

20. Du R, Auguste KI, Chin CT, Engstrom JW, Weinstein PR. Magnetic resonance neurography for the evaluation of peripheral nerve, brachial plexus, and nerve root disorders. J Neurosurg 2010;112:362-371.

21. Kim S, Choi JY, Huh YM, et al. Role of magnetic resonance imaging in entrapment and compressive neuropathy: what, where, and how to see the peripheral nerves on the musculoskeletal magnetic resonance image: part 1: overview and lower extremity. Eur Radiol 2007;17:139-149.

22. Trajman A, Luiz RR. McNemar chi2 test revisited: comparing sensitivity and specificity of diagnostic examinations. Scand J Clin Lab Invest 2008;68:77-80.

23. Nilsson J, Sandberg K, Soe Nielsen N, Dahlin LB. Magnetic resonance imaging of peripheral nerve tumours in the upper extremity. Scand J Plast Reconstr Surg Hand Surg 2009;43:153-159.

24. Merlini L, Vargas MI, Anooshiravani M, Viallon M, Fluss J, Hanquinet S. Look for the nerves! MR neurography adds essential diagnostic value to routine MRI in pediatric practice: a pictorial overview. J Neuroradiol 2011;38:141-147.

25. Filler AG, Maravilla KR, Tsuruda JS. MR neurography and muscle MR imaging for image diagnosis of disorders affecting the peripheral nerves and musculature. Neurol Clin 2004;22:643-682.

26. Lehmann HC, Zhang J, Mori S, Sheikh KA. Diffusion tensor imaging to assess axonal regeneration in peripheral nerves. Exp Neurol 2010;223:238-244.

27. Martinoli C, Derchi LE, Bertolotto M, et al. US and MR imaging of peripheral nerves in leprosy. Skeletal Radiol 2000;29:142-150. 